\title{
WORK PERFORMANCE: THE IMPACT OF WORK ENGAGEMENT, PSYCHOLOGICAL CAPITAL, AND PERCEIVED ORGANIZATIONAL SUPPORT
}

\author{
Kiky D.H. Saraswati ${ }^{1}$ dan Mirda Sari Ningtyas Dara Pertiwi ${ }^{2}$ \\ ${ }^{1}$ Program Studi Magister Psikologi, Universitas Tarumanagara Jakarta \\ Email: kikysaraswati@yahoo.com \\ ${ }^{2}$ Program Studi Sarjana Psikologi, Universitas Tarumanagara Jakarta \\ Email: darapertiwi97@gmail.com
}

Masuk: 16-04-2020, revisi: 30-04-2020, diterima untuk diterbitkan : 30-04-2020

\begin{abstract}
Work performance, undoubtedly, is the key of organizational success. Therefore, it is very important to find out the antecedents which will significantly lead to work performance. Unlike other organizations, mental hospital is a unique institution delivering a different kind of service, both to the patients as well as the family of the patients. Adding to the fact, nurses play a very important role in determining the performance of the hospital. Current study aimed to investigate the contributions of work engagement, psychological capital, and perceived organizational support towards work performance. This was a quantitative non-experimental research employing four questionnaire distributed to 140 nurses from all positions, ranging from junior to senior, and conducted in a mental hospital in Jakarta, Indonesia. The questionnaires distributed to participants were 47-item Individual's Work Performance, 3-item Utrecht Work Engagement Scale, 24-item Psychological Capital Questionnaire, and 8-item Survey of Perceived Organizational Support. The results of the study found that work engagement played a significant role towards work performance $(F=42.402, p<0,05)$. Moreover, psychological capital and perceived organization support contributed a significant impact towards work engagement $(F=3.678, p<0.05)$.
\end{abstract}

Keywords: work performance, work engagement, psychological capital, perceived organizational support

\begin{abstract}
ABSTRAK
Tidak diragukan lagi bahwa kinerja adalah kunci keberhasilan organisasi. Oleh karena itu, mengetahui anteseden yang secara signifikan akan mengarah pada kinerja sangat penting. Tidak seperti organisasi lain, rumah sakit jiwa adalah institusi unik yang memberikan layanan yang berbeda, baik untuk pasien maupun keluarga pasien. Ditambah juga perawat memainkan peran yang sangat penting dalam menentukan kinerja rumah sakit. Penelitian ini bertujuan untuk menyelidiki kontribusi keterlibatan kerja, modal psikologis, dan dukungan organisasi yang dirasakan terhadap kinerja kerja. Penelitian ini adalah penelitian kuantitatif non-eksperimental yang menggunakan empat kuesioner yang didistribusikan kepada 140 perawat dari berbagai posisi, mulai dari junior hingga senior, dan dilakukan di sebuah rumah sakit jiwa di Jakarta, Indonesia. Kuesioner yang dibagikan kepada peserta adalah Individual's Work Performance yang terdiri dari 47 item, Utrecht Work Engagement Scale yang terdiri dari 3 item, Psychological Capital Questionnaire yang terdiri dari 24 item, dan Survey of Perceived Organizational Support yang terdiri dari 8 item. Hasil penelitian menemukan bahwa keterlibatan kerja berperan penting terhadap kinerja kerja $(\mathrm{F}=42,402, \mathrm{p}$ $<0,05)$. Selain itu, modal psikologis dan dukungan organisasi yang dirasakan berkontribusi secara signifikan pada keterlibatan kerja $(\mathrm{F}=3,678, \mathrm{p}<0,05)$.
\end{abstract}

Kata Kunci: kinerja kerja, keterlibatan kerja, modal psikologis, dukungan organisasi yang dirasakan

\section{INTRODUCTION}

Organizational behavior is a field of study devoted to understanding, explaining, and ultimately improving the attitudes and behaviors of individuals and groups in organizations (Colquitt, LePine, \& Wesson, 2017). The results of the studies are then applied by managers or consultants to see whether they help meet "real-world" challenges. An indicator which is commonly applied to measure individual and group attitudes and behaviors within an organization is work performance. In other words, work performance is a critical concern for any managers because only the high performing individuals will contribute significantly for the organizational performance. 
Work performance is formally defined as the value of the set of employee behaviors that contribute, either positively or negatively, to organizational goal accomplishment (Colquitt et al., 2017). This definition includes behaviors that are within the control of employees, but it places a boundary on which behaviors are (and are not) relevant to work performance. Another definition of work performance is proposed by Campbel (Koopmans et al., 2013) who introduced this term as Individual Work Performance (IWP). IWP is defined as behaviors or actions that are relevant to the goals of the organization.

The domain of IWP consists of task performance, contextual performance, counterproductive work behavior, and adaptive performance. Task performance is defined as the proficiency with which individuals perform the core substantive or technical tasks central to his or her job. Behaviors used to describe task performance often include work quantity and quality, job skills, and job knowledge. Contextual performance can be defined as behaviors that support the organizational, social, and psychological environment in which the technical core must function. Behaviors used to describe contextual performance include, for example demonstrating effort, facilitating peer and team performance, cooperating, and communicating. CWB can be defined as behavior that harms the well-being of the organization. It includes behaviors such as absenteeism, off-task behavior, theft, and substance abuse. Adaptive performance can be defined as the extent to which an individual adapts to changes in the work role or environment. This dimension focuses on the growing interdependency and uncertainty of work systems and the corresponding change in the nature of IWP (Koopmans et al., 2013) Adaptive behaviors are becoming increasingly important as globalization, technological advances, and knowledge-based work increase the pace of change in the workplace. In fact, adaptive performance has become crucial in today's global economy where companies have been faced with challenge of becoming more productive with fewer employees on staff (Colquitt et al., 2017). As Ulrich (Schaufeli, 2013) wrote in his book Human Resources Champions, employee contribution becomes a critical business issue because in trying to produce more output with less employee input, companies have no choice but to try to engage not only the body but the mind and soul of every employee.

Furthermore, Schaufeli made it clearer that this statement is not only focusing on doing more with fewer people, but also the needs of employees who are able and willing to invest in their jobs psychologically.

In this case, work engagement plays an important role. Work engagement is defined as a positive, fulfilling psychological state that is characterized by vigor, dedication, and absorption (Schaufeli, 2017). Vigor is characterized by high levels of energy and mental resilience while working, the willingness to invest effort in one's work, and persistence even in the face of difficulties. Dedication refers to being strongly involved in one's work, and experiencing a sense of significance, enthusiasm, inspiration, pride, and challenge. Absorption is characterized by being fully concentrated and happily engrossed in one's work, whereby time passes quickly and one has difficulties with detaching oneself from work.

Unlike burnout, its antipode, work engagement is characterized by a high level of energy and strong identification with one's work. Those who scored high on UWES (Utrecth Work Engagement Scale) are active agents, who take initiative at work, and generate their own positive feedback loops. They are committed to performing at a high quality level and show that their values seem to match quite well with the organization's (Schaufeli \& Salanova, 2007). 
As suggested by Job-Demands and Resources (JD-R) Model, work engagement is enhanced by promoting the personal and job resources. The JD-R model proposes that employee well-being is related to a wide range of workplace characteristics that can be conceptualized as either job demands (i.e., the physical, social, or organizational aspects of the job that require sustained physical or psychological effort) or job resources (i.e., those aspects of the job that may reduce job demands, are instrumental to achieve work goals, or promote personal growth, learning and development). Excess job demands and lacking job resources exert an energydraining effect on employees through a stress process, while high levels of job resources are related to positive work outcomes through a motivational process (Hu, Schaufeli, \& Taris, 2011). the JD-R model also assumes two moderating effects, namely that: (1) job resources buffer the potentially negative effects of excessive job demands on employee health and well-being, while (2) highly demanding work situations in combination with high levels of job resources result in higher levels of work engagement (L, 2011).

Hobfoll, Johnson, Ennis, and Jackson (Bakker \& Leiter, 2010) defined personal resources as positive self-evaluation linked to resiliency and refer to individual's sense of their ability to control and impact toward their environment successfully. Moreover Sweetman and Luthans (Bakker \& Leiter, 2010) described that this concept is similar to psychological capital.

Psychological capital is an outgrowth of positive organizational behavior and is defined as an individual's positive psychological state of development characterized by: (1) having confidence (self-efficacy) to take on and put in the necessary effort to succeed at challenging tasks; (2) making a positive attribution (optimism) about succeeding now and in the future; (3) persevering toward goals, and when necessary, redirecting paths to goals (hope) in order to succeed; and (4) when beset by problems and adversity, sustaining and bouncing back and even beyond (resilience) to attain success (Luthans, Youssef, \& Avolio, 2007).

Self-efficacy represents the general belief of people while they exhibit their performances and makes a sense beyond the actual abilities that lead to complete tasks. It can be said that high self-efficacy can influence motivation in both positive and negative sides. People who are self-confident know how to improve their motivation. They choose challenging tasks to extend their performance and motivate themselves against the obstacles faced while working for accomplishing goals. Research by Stajkovic and Luthans underlined that there is a strong and positive relationship between self-efficacy and performance (Cavus \& Kapusuz, 2015).

Moreover, Cavus and Kapusuz (2015) explained that hope supports the desires of positive outcomes and gives the feeling of being good to make the dreams come true in human life. It can be determined as a feature which awakes people to get a motivation. Motivated people unselfishly work and perform their abilities. It can be said that hope is related to the motivation and that it has a positive and significant relationship with job satisfaction and performance. On the other hand, hope can be defined as an energy focused on the personal goals and a way or alternative ways which direct people to the target. Hope is a tool that motivates people while doing their job requirements. Several other researches also point out that hope is positively related to life satisfaction, work satisfaction and performance, and motivation to cope with stressful events.

Optimism can be defined as a psychological intension and expectation to hope the best possible and positive outcome which can positively influence peoples' mental and physical health. This gives individuals a chance to make their life more easy and leave out of stress. 
Optimists distance themselves from depression and hopelessness. Optimism can also be defined as a generalized expectation to have a better future. Optimist managers and sales representatives are much more succesfull than pessimist ones while playing their trade. Optimist people expect that positive situations will happen while pessimists are expecting that negative things will take place (Cavus \& Kapusuz, 2015).

Resiliency which is defined as a tendency to recover from adversity or depressing process, allows people to optimistically look at the overwhelming situations. Luthans and Youssef (Cavus \& Kapusuz, 2015) illustrated that resilient people can change for the better through the complexity. Resiliency has a reactional character that affects people to orient to the all kinds of situations faced in their life. Psychological resiliency is characterized as an ability for bouncing back, focusing on the goals and success. Masten put into words that resiliency has three manageable and developable components, such as asset factors that increase the level of personal resiliency, risk factors which guides to lower levels of resiliency, and influence processes. She also added that resilient people are able to succeed and learn something in mischance (Cavus \& Kapusuz, 2015).

Sweetman and Luthans (Bakker \& Leiter, 2010) concluded that individuals showing high level of psychological capital are more likely to experience positive emotions, while positive emotions have been consistently to lead to more social integration and a higher level of engagement. Positive emotions also may lead to increased levels of energy and vigor (a dimension of work engagement), and being more available to engage in a work role. Simmons and Buitendach (2013) concluded that psychological capital is positively and significantly related to work engagement and work commitment.

Engaged employees are committed to the organization that provides them with job resources that enable their work goals, presenting them with opportunities for learning, growth, and development (Demerouti, Bakker, Nachreiner, \& Schaufeli, 2001). Job resources refer to those physical, social, or organizational aspects of the job that may: (a) reduce job demands and the associated physiological and psychological costs; (b) be functional in achieving work goals; or (c) stimulate personal growth, learning, and development (Schaufeli \& Salanova, 2007). A variable that is closely related to job resources is perceived organizational support. Many previous studies have resulted on how perceived organizational support may lead to higher work engagement (Caesens \& Stinglhamber, 2014; Kose, 2016).

Perceived organizational support is accepted as the perception that workers are valued by the organization and their happiness is taken into account by the organization (Eisenberger, Huntington, Hutchison, \& Sowa 1986). The perception of organizational support is the extent of belief of workers that their organization appreciates their contributions and that it cares about their well-being (Robbins \& Judge, 2012). Hellman (2006) defines the perception of organizational support as workers' perceiving the acceptance of the contributions they make to the organization they work for as a result of their efforts by the organization and the attention the organization gives to its workers' well-being. While Martin (1995) defines organizational support as the awareness of workers' contribution by the organization and the importance that the organization gives to their well-beings. Eisenberger et al. (1986), in a different definition, described organizational support as the organizational values' taking workers' well-being into consideration and bearing the qualities that increase happiness of workers. 
Perceived organizational support would be influenced by various aspects of an employee's treatment by the organization and would, in turn, influence the employee's interpretation of organizational motives underlying that treatment. This implies that there will be agreement in the degree of support that the employee would expect of the organization in a wide variety of situations. These would include the organization's likely reaction to the employee's future illnesses, mistakes, and superior performance, and the organization's desire to pay a fair salary and make the employee's job meaningful and interesting. Perceived support would raise an employee's expectancy that the organization would reward greater effort toward meeting organizational goals (effort-outcome expectancy). To the extent that the perceived support also met needs for praise and approval, the employee would incorporate organizational membership into self-identity and thereby develop a positive emotional bond (affective attachment) to the organization. An effort-outcome expectancy and affective attachment would increase an employee's efforts to meet the organization's goals through greater attendance and performance (Eisenberger et al., 1986).

By meeting socioemotional needs, POS should increase identification with the organization, leading to greater affective organizational commitment. POS should also elicit the norm of reciprocity, leading to a felt obligation to help the organization as well as the expectation that increased performance on behalf of the organization will be rewarded. These factors should increase effort in standard job activities, resulting in enhanced in-role job performance and extra role performance and reduced withdrawal behaviors. In contrast, low POS should elicit the negative norm of reciprocity leading to behaviors intended to harm the organization and its representatives (Kurtessis et al., 2015).

Another approach was also introduced. An employee's increase in work effort resulting from development of a greater effort-outcome expectancy and affective attachment depends on an exchange ideology favoring the trade of work effort for material and symbolic benefits. Such exchange ideologies stem from the norm of reciprocity that holds that people should help those who have helped them. Perceived organizational support would be predicted to strongly influence the absenteeism and performance of individuals with a strong exchange ideology but to have little influence on those with a weak exchange ideology (Eisenberger et al., 1986).

Based on the description above, it is observed that work performance is contributed by positive affect, such as work engagement. Moreover, based on JD-R Models, work engagement is mostly influenced by personal and job resources. In this research, personal resource is represented by psychological capital, while job resource is represented by perceived organizational support. Therefore, the hypotheses of this study are as follows:

1. Work engagement contributes a significant impact towards work performance.

2. Psychological capital and perceived organizational support contribute a significant impact towards work engagement.

\section{RESEARCH METHODOLOGY}

A quantitative method was applied in this research. Data was collected by distributing questionnaires to 140 participants. The participants included nurses working at a hospital in Jakarta, Indonesia, at all levels, ranging from junior to senior positions. The participant's range of age is 23 to 59 years old. The majority of the participants was female, fell in the 30-40 years age group, and less than 10 years of service period. To have a better look, the demographics of the participants are described in the table below. 
Table 1: Demographic Characteristics of the Participants

\begin{tabular}{ccc}
\hline Age & $<29$ & $23.6 \%$ \\
& $30-49$ & $62.9 \%$ \\
& $>50$ & $13.6 \%$ \\
\hline Gender & Male & $37.14 \%$ \\
& Female & $62.86 \%$ \\
\hline Years of Service & $<10$ & $55.71 \%$ \\
& $10-20$ & $30 \%$ \\
& $>20$ & $14.29 \%$ \\
\hline
\end{tabular}

The questionnaires used in this study were 47-item Individual Work Performance Scale, 3item Utrecht Work Engagement Scale, 24-item Psychological Capital Questionnaire, and 8item Perceived Organizational Support Questionnaire. All of the questionnaires mentioned above had been translated to Bahasa Indonesia so that the participants would have had a better comprehension and they would have been able to deliver responses representing their actual perception towards the items, as expected.

Below is the Alpha Cronbach of the scales:

Table 2: Alpha Cronbach

\begin{tabular}{lc}
\hline \multicolumn{1}{c}{ Scale } & Alpha Cronbach \\
\hline Individual Work Performance & 0.949 \\
& \\
Work Engagement & 0.839 \\
Psychological Capital & 0.876 \\
Perceived Organizational Support & 0.929 \\
\hline
\end{tabular}

Table 3: Mean of All Variables by Demographic Characteristics

\begin{tabular}{cccccc}
\hline \multicolumn{2}{c}{ Characteristics } & \multicolumn{4}{c}{ Mean } \\
\cline { 3 - 6 } & & WP & WE & PC & POS \\
\hline Age & $<29$ & 3.89 & 4.01 & 3.84 & 4.65 \\
& $30-49$ & 3.84 & 3.95 & 3.80 & 4.61 \\
& $>50$ & 4.06 & 3.85 & 3.79 & 4.82 \\
\hline Gender & Male & 3.83 & 3.80 & 3.74 & 4.54 \\
& Female & 3.92 & 4.04 & 3.85 & 4.71 \\
\hline Years & $<10$ & 3.92 & 4.08 & 3.81 & 4.54 \\
of & $10-20$ & 3.77 & 3.74 & 3.84 & 4.74 \\
Service & $>20$ & 4.00 & 3.95 & 3.73 & 4.79 \\
\hline
\end{tabular}

The result of data analysis to investigate the hypotheses are described below.

An example of Individual Work Performance item is "Seberapa seringkah kualitas pekerjaan Anda berada di bawah yang seharusnya dalam tiga bulan terakhir?". In Utrecht Work Engagement Scale, one of the item is "Saya bekerja dengan penuh energi". While in Psychological Capital Questionnaire we used items such as "Saya merasa yakin saya mampu mengkaji permasalahan yang tidak kunjung terselesaikan hingga menemukan pemecahannya", and the example of the item in the Survey of Perceived Organizational Support is "Perusahaan akan membantu bila saya memerlukan bantuan khusus". 
The statistical analysis was carried out with the SPSS Program version 21, using descriptive statistics, Cronbach's alpha, and linear regression.

\section{RESULTS AND DISCUSSION}

The mean of all variables is above the hypothetical mean. It indicates that the respondents show good work performance (WP), work engagement (WE), psychological capital (PC), and perceived organizational support (POS). The details are shown in the tables below.

Hypotheses 1: Work engagement contributes a significant impact towards work performance.

The data analysis found that work performance could be predicted by psychological capital through work engagement as moderating variable $(\mathrm{F}=42.402, \mathrm{p}<0,05)$. The complete result is shown in the table below.

Table 4: Linear Regression Analysis of Work Engagement and Work Performance

\begin{tabular}{lccll}
\hline & $\begin{array}{l}\text { Sum of } \\
\text { Squares }\end{array}$ & df & $\begin{array}{l}\text { Mean } \\
\text { Square }\end{array}$ & F \\
\hline Regression & 781.778 & 1 & 781.778 & 2.402 \\
\hline Residual & 090.62 & 38 & 54.280 & \\
\hline Total & $\begin{array}{l}072.40 \\
0\end{array}$ & 39 & & \\
\hline
\end{tabular}

Further analysis also found that the independent variables contributed $23.5 \%$ impact towards work performance. The result of the analysis is shown in table below.

Table 5: Contribution of Work Engagement towards Work Performance

\begin{tabular}{cccc}
\hline $\mathrm{R}$ & R Square & $\begin{array}{c}\text { Adjusted } \\
\text { R Square }\end{array}$ & $\begin{array}{c}\text { Std. Error } \\
\text { of the } \\
\text { Estimate }\end{array}$ \\
\hline .485 & .235 & .229 & 15.94616
\end{tabular}

Hypotheses 2: Psychological capital and perceived organizational support contribute a significant impact towards work engagement

The data analysis found that work engagement could be predicted by both psychological capital and perceived organizational support $(\mathrm{F}=3.678, \mathrm{p}<0,05)$. The complete result is shown in the table below.

Table 6: Linear Regression Analysis of Psychological Capital, Perceived Organizational Support, and Work Engagement

\begin{tabular}{llllll}
\hline & $\begin{array}{l}\text { Sum of } \\
\text { Squares }\end{array}$ & df & $\begin{array}{c}\text { Mean } \\
\text { Square }\end{array}$ & F & Sig. \\
\hline Regression & 34.505 & 2 & 17.252 & 3.678 & .028 \\
\hline Residual & 642.638 & 137 & 4.691 & & \\
\hline Total & 677.143 & 139 & & & \\
\hline
\end{tabular}


Moreover, both variables contributed $5.1 \%$ impact towards work performance. The analysis result is shown in table below.

Table 7: Contribution of Psychological Capital and Perceived Organizational Support towards Work Engagement

\begin{tabular}{cccc}
\hline R & R Square & $\begin{array}{c}\text { Adjusted R } \\
\text { Square }\end{array}$ & $\begin{array}{c}\text { Std. Error of } \\
\text { the Estimate }\end{array}$ \\
\hline .226 & .051 & .037 & 2.16582 \\
\hline
\end{tabular}

The objective of this study was to examine the impact of work engagement towards work performance and the impact of psychological capital and perceived organizational support towards work engagement. The results showed that both hypotheses were significantly proven.

Regarding the impact of work engagement towards employee's work performance, Kahn suggested that individuals who invest physical, cognitive and emotional energies into their work assignments demonstrate broader mindfulness and connectedness to their tasks. Such engagements foster active, complete role performances through behavior that is extra conscientious, interpersonally collaborative, innovative and involved. Adding to the fact, engaged individuals have extra energy to go beyond their tasks and to fulfill others requirements when it is needed. Similarly, previous empirical studies have also shown that engagement related to task performance and contextual performance (Bakker \& Leiter, 2010). The results of the data analysis due to the role of work engagement as an antecedent to promote work performance aligned with the previous studies.

Further explanation was delivered by Sweetman and Luthans (Bakker \& Leiter, 2010), that psychological capital enables individuals to experience positive emotions, even when the events are perceived as a stressful situation by their co-workers. Reviewing the research result, it can be concluded that psychological capital is considered as a source of positive emotion that will result in work engagement. On the contrary, when the psychological capital is absent, the employee may experience burnout, which is also known as the antipode of work engagement. Simons and Buitendach (2013) also found in their research that psychological capital among call center employees is positively related to work engagement. Alessandri, Consiglio, Luthans, and Borgogni (2018) found that increases in psychological capital and work engagement would increase the employee's work performance as well. They gave further explanation that the results support the conservation of resources theory, in which employees are motivated to acquire, protect and foster their valued (psychological) resources to attain successful performance outcomes, in order to create a gain cycle of resources. This leads to empirical validation that processes, like work engagement, are sustained by personal resources, in this case psychological capital, and that these latter exerts mostly an indirect effect on organizational behavior outcomes.

The study which was conducted by Yongxing, Hongfei, Baoguo, and Lei (2017) found that work performance was influenced by work engagement and perceived organizational support. They argued that the individuals who received high organizational support would also perceived high duty or obligation to help the organization to achieve the goals for the reciprocity norm. Furthermore, when the employees perceived high organizational support, 
they would direct their engagement to the crucial task rather than other irrelevant behaviors.

The findings of this study also have potential implications for practice. As described before, work performance is significantly influenced by work engagement, while work engagement is significantly influenced by psychological capital and perceived organizational support. Thus, the practical implications will be suggested accordingly.

Firstly, to promote the employee's psychological capital, conducting training program is the most recommended step. In the training sessions, employees are informed the strategies and how to maintain their psychological capital levels. It is also suggested to implement a good employee selection battery and retaining program for employees who show higher levels of psychological capital. This will be valuable to contribute to their work performance.

Secondly, the organization should increase the perceived organizational support by showing them that the organization cares, approve, and respect their contributions. Moreover, the organization should also fulfil the employee's socioemotional needs and promote the sense of organizational membership as their social identity.

\section{Acknowledgements}

The authors would like to express gratitude to the Faculty of Psychology of Universitas Tarumanagara, Jakarta for the support contributed to this research.

\section{REFERENCES}

Alessandri, G., Consiglio, C., Luthans, F., \& Borgogni, L. (2018). Testing a dynamic model of the impact of psychological capital on work engagement and job performance. Career Development International, 23(1), 33-47.

Bakker, A. B., \& Leiter, M. P. (2010). Work engagement: A handbook of essential theory and research. New York, NY: Psychology Press.

Caesens, G., \& Stinglhamber, F. (2014). The relationship between perceived organizational support and work engagement: The role of self-efficacy and its outcomes. Revue Européenne de Psychologie Appliquée/European Review of Applied Psychology, 64(5), 259-267.

Cavus, M. F., \& Kapusuz, A. G. (2015). Psychological capital: Definition, components, and effects. British Journal of Education, Society, and Behavioural Science, 5(3), 244-255.

Colquitt, J. A., LePine, J. A., \& Wesson, M. J. (2017). Organizational behavior: Improving performance and commitment in the workplace $\left(5^{\text {th }}\right.$ Ed.). New York, NY: McGraw-Hill Education.

Demerouti, E., Bakker, A. B., Nachreiner, F., \& Schaufeli, W. B. (2001). The job demands-resources model of burnout. Journal of Applied Psychology, 86, 499-512.

Eisenberger, R., Huntington R., Hutchison S., \& Sowa, D. (1986). Perceived organizational support. Journal of Applied Psychology, 7, 500-507.

Hellman, C. M., Fuqua, D. R., \& Worley, J. (2006). A Reliability generalization study on the survey of perceived organizational support: The effects of mean age and number of items on score reliability. Educational and Psychological Measurement, 66(4), 631- 642 .

Hu, Q., Schaufeli, W. B., \& Taris, T. W. (2011). The job demands-resources model: An analysis of additive and joint effects of demands and resources. Journal of 
Vocational Behavior, 79(2011), 181-190.

Koopmans, L., Bernaards, C., Hildebrant, V., Van Buuren, S., Van Der Beek, A.J., \& De Vet, H. C. W. (2013). Development of an individual work performance questionnaire. International Journal of Productivity and Performance Management, 6-28.

Kose, A. (2016). The relationship between work engagement behaviour and perceived organizational support and organizational climate. Journal of Education and Practice, 7(27), 42-52.

Kurtessis, J. N., Eisenberger, R., Ford, M. T., Buffardi, L. C., Stewart, K. A., \& Adis, C. S. (2015). Perceived organizational support: A meta-analytic evaluation of organizational support theory. Journal of Management.

Luthans, F., Youssef, C. M., \& Avolio, B. J. (2007). Psychological capital: Developing the human competitive edge. Oxford, UK: Oxford University Press.

Martin, R. (1995). The roles of organizational support and justice during a layoff. Academy of Management Journal, 1, 89-93.

Robbins, S., \& Judge, T. (2012). Organizational behavior (Inci Erdem, Trans.). Istanbul: Nobel.

Schaufeli, W. B. (2013). What is engagement? In C. Truss, K. Alfes, R. Delbridge, A. Shantz, \& E. Soane (Eds.), Employee Engagement in Theory and Practice. London: Routledge.

Schaufeli, W. B. (2017). Applying the job demands-resources model: A 'how to' guide to measuring and tackling work engagement and burnout. Organizational Dynamics, $46,120-132$.

Schaufeli, W. B., \& Salanova, M. (2007). Work engagement: An emerging psychological concept and its implications for organizations. Managing Social and Ethical Issues in Organizations, 135-177.

Simons, J. C., \& Buitendach, J. H. (2013). Psychological capital, work engagement and organisational commitment amongst call centre employees in South Africa. South Africa Journal of Industrial Psychology, 39(2), 1-12.

Yongxing, G., Hongfei, D., Baoguo, X. \& Lei, M. (2017). Work engagement and job performance: The moderating role of perceived organizational support, Anales de Psicologia/Annals of Psychology, 33(3), 708-713. 